\title{
Discussions on Improving the Exhibition Archives Administration
}

\author{
Bo Zhang ${ }^{1}$ \\ ${ }^{1}$ The Engineering \& Technical College of Chengdu University of Technology, Leshan City, Sichuan \\ Province, China
}

Keywords: exhibition industry; archives administration; countermeasure; innovation.

\begin{abstract}
In recent years, China's exhibition industry is booming, especially in some economically developed regions. The exhibition industry has brought about more and more benefit and promoted the economic development of many areas. The exhibition industry is naturally regarded by a lot of people think as a sunrise industry. In addition, the exhibition industry carries out the different activities and project $\mathrm{s}$ from the other industries, mainly reflecting in the wide coverage of the audience. In addition, the exhibition industry is closely related to the modern people's daily lives. Therefore, on the other hand, people's requirements for the exhibition industry are becoming increasingly strict. In this process, it is the focus of our work to make the exhibition archive administration constantly adapt to the new environment. The purpose of this study is to improve the exhibition archives administration, issue the scientific and effective regulations of the exhibition industry administration, further strengthen the communication between the exhibition industry and the other industries, help to build the corresponding exhibition archives administration model. Thus, we can fully show the value of the archives administration in the exhibition industry and analyze the thinking ideas and countermeasures of the exhibition archives administration innovation in the new period.
\end{abstract}

\section{Introduction}

Generally speaking, on the basis of this special environment in the new period and most of the exhibitors' present status, this paper analyzed a series of the innovative exhibition archives administration, and then launched abundant studies on it. This paper analyzed all kinds of difficult problems of archives administration in the new period from several aspects, put forward the solutions to solve the problems, so as to complete the strategic study on the system and establish the thinking mode of innovation research. [1] In this process, the exhibition archives administration continuously adapts to the special environment in the new period, which is the focus of our work. Meanwhile, for the entire industry to establish a good point to the standard direction, so as to improve and broaden the research ideas of the innovation of the exhibition archives administration.

\section{China's Exhibition Industry in the New Era}

Exhibition industry in China. The exhibition industry, the tourism industry and the real estate industry are known as the world's three smokeless industry [2]. In the world, the exhibition industry is divided into the conference industry and the display industry. The exhibition industry should be regarded as the rising service industry of the beginning of the tertiary industry, which has always been a close relationship with other industries and a wide coverage of audience, etc. In addition, the exhibition industry has its own unique advantages. It has been praised by everyone, which means that the exhibition industry should follow the trend of the times。 Its efficiency and progress of the work has been dominating. It also makes great achievements in the 4P marketing. Overall, the exhibition industry in China has continuously optimized the allocation and integration of resources, enhancing its ability and level to ensure its competitive enough. In addition, the exhibition activities can also provide enough jobs and promote the local economic and social development.

Problems in the development of the exhibition industry in China. In the development of China's exhibition industry, there are many problems need to be solve. In this process, the most important is to focus on the exhibitors who have not devoted enough enthusiasm in the archives 
administration. They do not understand the motivation and soul of the activities. They just well behave to perform their daily tasks without any suitable regulation. They do not make any innovation and show a negative attitude. This is not what we pursuit. [3] According to the relevant researches, it is fund out that whether the large or small sized enterprises, few of them have a clear administration system in the archives administration. They have not established a perfect relevant examination mechanism. They even have some unnecessary problems in some adjustment control mode. The archives with a long history and the same type has not been classified to save, causing the problem of dissatisfaction and complaints. These problems are worth studying. Some enterprises lack the necessary personnel administration, which leads to the low working efficiency. In some procedures, the workers are not skilled enough and the enterprises have not the professional people who are responsible for the relevant filing and training [4]. For example, during the period of a large-scale exhibition, the enterprise will receive heavy tasks. However, the number of the full-time employees are far less than needed. In the activities, the enterprises have to temporarily recruit the part-time students two or three days before the activity. Because of the temporary appointment, they cannot smoothly deal with many issues and affect the team's work and the exhibition activities. Therefore, this will finally cause the success of the exhibition.

\section{Innovative Ideas to Improve the Archives Administration in the New Era}

At present, many problems need to be solved to perfect the exhibition archives administration in the new period. In this process, the most important is to focus on the exhibitors who have not devoted enough enthusiasm in the archives administration. They do not understand the motivation and soul of the activities. They just well behave to perform their daily tasks without any suitable regulation. They do not make any innovation and show a negative attitude. First of all, the establishment of the exhibition archives administration system is conducive to the balance of the whole exhibition activities, which not only can identify and weigh the pros and cons, but also find out the center of our work [5]. In recent years, the exhibitors continuously expand the scale and exhibits of the exhibition, but also imminent how to improve the archives administration system of the exhibition. The following suggestions of the innovative construction are worthy for the builders and managers in universities and colleges.

To enhance the understanding of the concept of exhibition archives administration. First of all, any department and personnel should consciously enhance the exhibition of archives administration to improve the early exhibition of the archives administration so as to solve the problems in the pre-exhibition activities of archives administration. Some enterprises are lack of preparation, even temporarily recruit some part-time staff to participate in the activities two or three days before the activities. Because of the temporary appointment, they cannot smoothly deal with many issues and affect the team's work and the exhibition activities. Therefore, the insufficient understanding of the archives administration idea will cause obvious and huge loss. And all the exhibitors, including the department leaders, should make clear their own administration consciousness to ensure that all the activities can smoothly carried out [6]. For example, the people in charge who are responsible for the activities should prepare for the exhibition and the related information a week before the activities, sign a cooperation agreement with the partners, ensure that someone is responsible for each program, normalize all the work in the exhibition, establish and improve the relevant administration system, guarantee the smoothly exhibition, determine the main direction of all the work and further make clear the working ideas. On the other hand, we can also put forward the innovative feasible countermeasures in order to ensure the ideas and measures launched simultaneously, which is the direction of the work in the future [7].

To improve the administration of exhibition archives. The exhibition industry can learn from the advanced administration center of the archives administration. Thus, the exhibitors should take their own advantages, establish the relevant regulations, establish and improve the relevant institutional mechanisms, so as to complete the information construction of the exhibition industry. Nowadays, with the rapid development of the science and technology of the times, the archives administration method used by some exhibitors in the previous stage are too complex and too 
traditional. Therefore, they cannot get the favor of the customers. In addition to these methods, the regular archives material is too simple and there is no innovation nor improvement ideas. On the other hand, most of the exhibition materials are paper, which can keep complete and is easy to handle, so these materials naturally become the most popular form of the exhibition archives administration. On the other hand, the electronic archives have not been popular. The usage of the electronic records can significantly save some unnecessary procedures, making the work scientific and rational. With the procedure of the science and technology in the new age, the electronic archives will become a mainstream way in the future, which will be accepted by more and more people. The exhibitors should constantly improve the exhibition archives administration mode and promote the sound development of the whole industry.

To strengthen the propaganda of the exhibition archives administration. In fact, an important issue is the exhibition archives administration has not enough propaganda. Because on the one hand, the archives administration can literally be considered a secret. Many enterprises have strict archives administration. Others are not limited to enter, even the universities have set up the major of archives. However, many people feel that this major is quite difficult to learn. All these are the society and the people's misunderstanding of archives. The most important reason is that the exhibition industry has not enough propaganda, so that we should make more people involved in this occupation and make clear of what the occupation does. They do not understand the true meaning of the industry and they just listen to other people according to the literal meaning, which are not desirable. Therefore, we need propaganda to solve this problem. The archives department should organize relevant activities and public exhibitions, strengthen the people's understanding of this area, which can not only help the people get rid of the unclear understanding of archives administration, but also improve the working enthusiasm of the employees, enhance the value of archives, bring huge benefits for the entire industry, so as to enhance the development of the whole industry.

\section{Conclusions}

Generally speaking, on the basis of this special environment in the new period and most of the exhibitors' present status, this paper analyzed a series of the innovative exhibition archives administration, and then launched abundant studies on it. This paper analyzed all kinds of difficult problems of archives administration in the new period from several aspects, put forward the solutions to solve the problems, so as to complete the strategic study on the system and establish the thinking mode of innovation research. The author analyzed the advantages of the new era environment for the exhibition archives administration and the existing problems in the construction. In recent years, China's exhibition industry is booming, especially in some economically developed regions. The exhibition industry has brought about more and more benefit and promoted the economic development of many areas. The exhibition industry is naturally regarded by a lot of people think as a sunrise industry. In addition, the exhibition industry carries out the different activities and project s from the other industries, mainly reflecting in the wide coverage of the audience. In addition, the exhibition industry is closely related to the modern people's daily lives. Therefore, on the other hand, people's requirements for the exhibition industry are becoming increasingly strict. In this process, it is the focus of our work to make the exhibition archive administration constantly adapt to the new environment. The purpose of this study is to improve the exhibition archives administration, issue the scientific and effective regulations of the exhibition industry administration, further strengthen the communication between the exhibition industry and the other industries, help to build the corresponding exhibition archives administration model. Thus, we can fully show the value of the archives administration in the exhibition industry and analyze the thinking ideas and countermeasures of the exhibition archives administration innovation in the new period.

\section{References}

[1] Liang Guo. Analysis of the Problems and Countermeasures in the Archives Administration of Public Institutions [J]. Economic Management (Full Version), 2016(9): 00241-00242. 
[2] Lin-han Sheng. Analysis on the Countermeasures of Improving the Exhibition Archives Administration [D]. Heilongjiang University, 2014.

[3] Wei-qiong Zhang. Analysis on the Problems and Countermeasures of the Utilization of Real Estate Registration Archives [J]. Archives Science Bulletin, 2016(5): 62-66.

[4] Hui Jiang, Yan Kong \& En-xian Liu. The Research on the Characteristics and Countermeasure of the Discipline Construction Archives Management under the New Situation [J]. Arhives of Shanxi, 2015(2): 105-107.

[5] Tao Su. Analysis and Countermeasures on the Problems of College Students' Archives Administration [J]. Zhejiang Archives, 2015(2): 60-60.

[6] Xie-zhou Wang \& Xiao-ning Luo. Research on Curriculum Resources Construction of Library and Information and Archives Management (Four) -- the Concrete Countermeasures of Curriculum Construction [J]. Archives Science Bulletin, 2015(2): 71-75.

[7] Hai-ying Chen. Thoughts and Countermeasures on Improving the Level of Archives Administration in Colleges and Universities under the New Situation [J]. Liaoning Economy, 2014(4):84-85. 